\title{
Characterization of Cassava Stems as Potential Biomass for Bio-Oil Production via Electromagnetic- Assisted Catalytic Liquefaction
}

\author{
L Lismeri $^{1, *}$, M Anggraini $^{1}$, A Sudarni $^{1}$, Y Darni $^{1}$ \\ ${ }^{1}$ Department of Chemical Engineering, Universitas Lampung, Jl. S. Brodjonegoro No. 1, Bandar Lampung, Indonesia \\ ${ }^{*}$ Corresponding author Email: lismeri@yahoo.co.id
}

\begin{abstract}
The production of bio-oil from biomass as renewable sources has been trusted as a suitable alternative in supplying future energy needs. Present in abundance amounts as crop residues cassava stems is potential biomass tobe utilized. As raw material, it has advantages such as fast and easy growth, minimal maintenance and utilizing plantation land without competing with food supply. The biomass characterization results showed that cassava stems containing cellulose, hemicellulose and lignin, respectively $40.16,25.66$ and $16.65 \%$ w/w. Cassava stems has low ash content and high of volatile matter with high carbon and low nitrogen. The HHV of cassava stems was $19.08 \mathrm{MJ} / \mathrm{kg}$.Physical propertiesby GC-MS tests of bio-oil produced via electromagnetic-assisted catalytic liquefaction(EA-CL)revealedthat the dominant content of chemicals were 5-methyl furfural, 2-furancarboxaldehyde and acetic acid.The bio-oil density ranged from 0.979 to $0.984 \mathrm{~g} / \mathrm{mL}$ and has a $\mathrm{pH}$ of 2.8 . This result shows that cassava stemis appropriate biomass for further bio-oil production feedstock.Bio-oil using EA-CL process meets bio-oil standards.
\end{abstract}

Keywords: Liquefaction, Biomass, Biooil, GC-MS

\section{INTRODUCTION}

Supported by geological conditions and geographical location, Indonesia has an abundant potential renewable resources. Based on data from the Ministry of Agriculture [1], the development of cassava productivity has increased by $3.84 \%$ per year over the past five years. The increase in cassava production is considered not optimal because it produces large cassava stem as residues. Only about $10 \%$ can be reused for planting and then the remaining $90 \%$ end in the open burning process and cause air pollution for human life. Cassava stems biomass rich of lignocelluloses which is potential as a raw material in the manufacture of bio-oil. It is major component are $39.30 \%$ cellulose, $24.34 \%$ hemicellulose and $13.42 \%$ lignin [2].

Generally, there are two types of processes in bio-oil production from biomass i.e. pyrolysis and hydrothermal liquefaction [3]. Production of bio-oil by pyrolysis process requires a relatively high temperature and the use of powder catalysts gives a greater amount of liquid in the product than using a lump catalyst [4]. The use of commercial residue catalytic cracking (RCC) which contains $\mathrm{Si} / \mathrm{Alas}$ a catalyst provide the best bio-oil products with low oxygenating compounds due to better crystal strength of catalyst[5].The use of electromagnetic field induction gives a high yield of glucose in concentrated acid hydrolysis of cassava stem with mild operating conditions at $160^{\circ} \mathrm{C}$ [6]. The existence of electromagnetic field induction, the lignocelullosic chain cracking process into glucose can be achieved at medium levels of temperature by arranging the direction of the magnetic moment of the particle nucleus and make it more reactive.

This study is intended to characterize the cassava stems biomass as raw material for bio-oil production and consider aspects relating to the production of bio-oil from cassava stems with the catalyst $\mathrm{Si} / \mathrm{Al}$ using electromagnetic reactors for reduce the energy consumption. Variables such as the number of catalysts and the length of electromagnetic field induction that affects the results and characteristics of bio-oil are studied. 


\section{MATERIAL AND METHODS}

Cassava stems used in this study were taken from Central Lampung, Lampung, Indonesia. The chemical used in this study were: phosphoric acid (H3PO4).The convertion process of the cassava stems into bio-oil, conducted in three main steps. First, mix and preheatingthe cassava stems fiber, $\mathrm{Si} / \mathrm{Al}$ catalyst, and phosphoric acid as solution. The process followed by the induction of electromagnetic field. The last process was boiling the mixture to obtain thebio-oil in the form of condensate and residues.

\subsection{Cassava Stems and Catalyst Preparation}

The cassava stems were washed, peeled and separated from the cork and the bark. Further then the stem cutted into smaller pieces, and then dried under the sun. The dried cassava stem was grounded into a fiber, sifted by using a $1.18 \mathrm{~mm}$ sieve.The sample was then dried in an oven at $100^{\circ} \mathrm{C}$ until it reached a constant weight. The fiber obtained was them immediatly analysis (including humidity, ash, volatile matter and fixed carbon amount), the elemental analysis (determination of the percentage of $\mathrm{C}, \mathrm{H}, \mathrm{O}$ and $\mathrm{N}$ ) and the high heating value analysis of the sample. The catalyst in the form of powder was activated by heating it in a furnace with a temperature of $550^{\circ} \mathrm{C}$ for 2 hours.

\subsection{Pre-Treatment}

Samples of 20 gram cassava stems, $200 \mathrm{ml}$ phosphoric acid solutions $85 \%, \mathrm{Si} / \mathrm{Al}$ catalysts, and magnetic stirrers were transferred into a two-part neck flask equipped with a thermometer and condenser, while the other parts were closed tightly. The mixture was heated for 20 minutes at $100^{\circ} \mathrm{C}$. After mixing and preheating, an electromagnetic field induction was carried out. The mixture wasboiled at a temperature of $160^{\circ} \mathrm{C}$. The study was conducted using a ratio of the number of catalysts that varied from 4 to 16 gram and the electromagnetic field induction has taken place for 60 and 90 minutes. The experimental scheme was shown in Figure 1. Because of the boiling process, the vapour was producedand then condensed inside the condenser with water cooling, so that condensate results would be obtained in the form of bio-oil condensate.

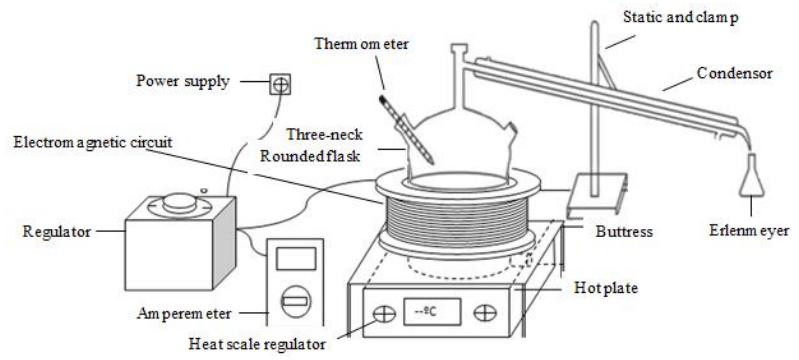

Figure 1 Electromagnetic reactor.

\section{RESULT AND DISCUSSION}

\subsection{Proximate and Ultimate Analysis}

The result of the proximate and ultimate analysis of samples are listed in Table 1. Cassava stems have a relatively high volatile matter i.e. $72.36 \%$. The volatile matter were related with the reactivity of the fuel [7] and indicated the high in liquid yield production [8]. The biomass ash content is mostly less than $20 \%$ dry basis. The lower the ash content, the higher the effectivity of the oxidation process[9]. The ash content of cassava stems is relatively low i.e. $1.84 \%$ compared by Imperatacylindrica. High mineral content indicates high ash content. Wherein, the presence of ash content will have detrimental on the bio-oil production, such as fouling, erosion, and slugging. The $\mathrm{N}$ content obtained from the ultimate analysis was 1.12 , which is desirable due to the lower NOx emission during the process conversion. $\mathrm{O} / \mathrm{C}$ and $\mathrm{H} / \mathrm{C}$ ratios are show the amount of potential it has to be used as raw material. The lower $\mathrm{H} / \mathrm{C}$ and $\mathrm{O} / \mathrm{C}$ indicated the higher energy of the biomass. Cassava stem results have $\mathrm{H} / \mathrm{C}=1.83$ and $\mathrm{O} / \mathrm{C}=0.84$. This value is lower than previous studies conducted by $\mathrm{E}$. R Zanatta [10] with $\mathrm{H} / \mathrm{C}=2.02$ and $\mathrm{O} / \mathrm{C}=0.98$. Based on the Van Krevelen diagram of coal and biomass issued by Hidayat [8], the plot of $\mathrm{H} / \mathrm{C}$ and $\mathrm{O} / \mathrm{C}$ of cassava stem are still included in the region of biomassas potential raw material compare with the coal.

The higher heating value (HHV, cross heating value) indicate the heat of combustion relative to liquid water as the product. Biomass heating value varies from $10 \mathrm{MJ} / \mathrm{kg}$ until $50 \mathrm{MJ} / \mathrm{kg}$ [9]. The $\mathrm{HHV}$ of cassava stem was $19.08 \mathrm{MJ} / \mathrm{kg}$, calculated by correlations developed by Nhuchhen[11],using proximate analysis data obtained as below:

$$
\mathrm{HHV}=0.1846 \mathrm{VM}+0.3525 \mathrm{~F}
$$

Table 1. Comparation proximate and ultimate analysis of cassava stem and literature characterization data.

\begin{tabular}{|c|c|c|c|}
\hline \multirow{3}{*}{$\begin{array}{c}\text { Analysis } \\
\text { Parameters }\end{array}$} & \multicolumn{3}{|c|}{ Biomass } \\
\hline & \multirow{2}{*}{$\begin{array}{c}\text { This } \\
\text { Experiment } \\
\text { CS }\end{array}$} & \multicolumn{2}{|c|}{ Literature } \\
\hline & & IC [8] & CB [10] \\
\hline \multicolumn{4}{|c|}{ Proximate Analysis"(wt.\%) } \\
\hline Moisture & 9.60 & 6.80 & 7.60 \\
\hline Ash & 1.84 & 2.97 & 1.02 \\
\hline VM & 72.36 & 72,01 & 81,70 \\
\hline
\end{tabular}




\begin{tabular}{|l|r|r|r|}
\hline FC & 16.22 & 18.21 & 9,68 \\
\hline
\end{tabular}

\begin{tabular}{|c|c|c|c|}
\hline \multirow{3}{*}{$\begin{array}{c}\text { Analysis } \\
\text { Parameters }\end{array}$} & \multicolumn{3}{|c|}{ Biomass } \\
\hline & \multirow{2}{*}{$\begin{array}{c}\text { This } \\
\text { Experiment } \\
\text { CS }\end{array}$} & \multicolumn{2}{|c|}{ Literature } \\
\hline & & IC [8] & CB [10] \\
\hline \multicolumn{4}{|c|}{ Elemental Analysis\# (wt.\%) } \\
\hline C & 43.58 & 44.38 & 40.4 \\
\hline $\mathrm{H}$ & 6.65 & 5.65 & 6.8 \\
\hline N & 1.12 & 0.82 & 0.1 \\
\hline $\mathrm{O}^{*}$ & 48.65 & 49.06 & 52.7 \\
\hline $\mathrm{O} / \mathrm{C}^{* \star}$ & 0.98 & 0.83 & 0.98 \\
\hline $\mathrm{H} / \mathrm{C}^{* *}$ & 2.02 & 1.53 & 2.02 \\
\hline \multicolumn{4}{|c|}{ Heating Value (MJ/Kg) } \\
\hline $\mathrm{HHV}$ & 19.08 & 18.47 & 15.27 \\
\hline \multicolumn{4}{|c|}{ Compositional Analysis" (wt.\%) } \\
\hline Cellulose & 40.16 & 44.49 & 28.50 \\
\hline Hemicellulose & 25.66 & 25.13 & 31.30 \\
\hline Lignin & 16.65 & 17.89 & 22.20 \\
\hline
\end{tabular}

$\mathrm{VM}=$ Volatile matter, $\mathrm{FC}=$ Fixed Carbon, $\mathrm{CS}=$ cassava stem, IC = Imperata Cylindrica, $\mathrm{CB}=$ Cassava Bagasse

* by difference

** molar ratio.

\# based on dry basis.

\subsection{Decomposition of Cassava Stem in EA-CL Process}

The composition of cassava stem as raw material in bio oil production via EA-CL was change in the form and number. Cassava stem was converted into product i.e. bio-oil and char. The more bio oil produced, the more lignocellulose is converted. In this experiment using EA$\mathrm{CL}$, the lignocellulose component was decomposed and decrease. Figure2, shows the decrease in the lignocellulose component number during the EA-CL process. Based on the result, the more catalysts usedand the longer the electromagnetic field induced give the highest value of the product produced and the lignocellulose reduction. The concentrated phosphoric acid is also used in this experiment to increase cellulose reactivity and make the lignocelluloses bond more amorphous [13]. By using concentrated acids, hydrolysis can also be done at lower temperatures [14].

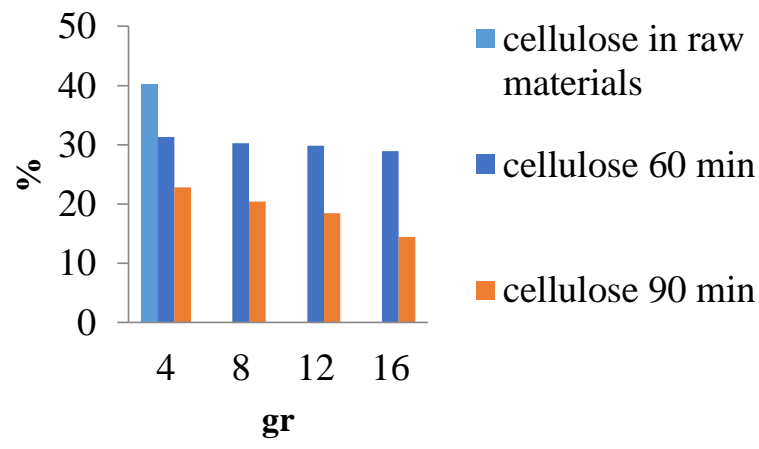

(a)

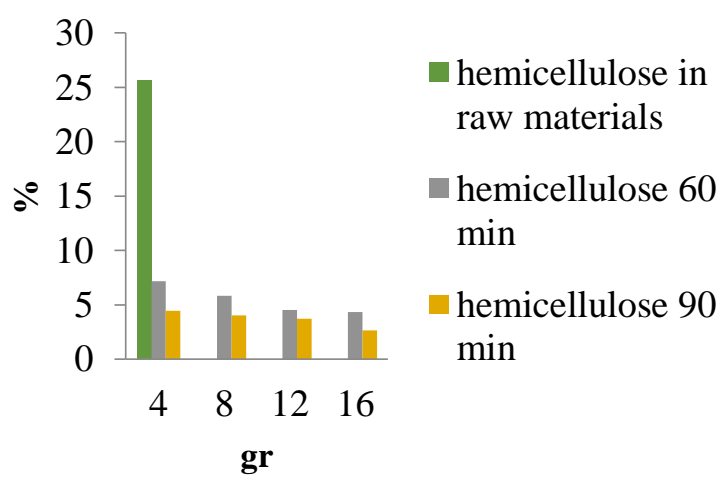

(b)

Figure 2 Decreased levels on lignocellulose (a) 60 minutes and (b) 90 minutes.

The electromagnetic field can change the distribution of charge in solvents and the area around it becomes stronger. This electromagnetic field will also change the chemical structure of the solvent and increase the solvent density significantly so that the state of the molecule whose activity is more active will cause low molecular bonds. Low molecular bond energy will cause bonding between molecules easier to break with lower energy [15]. So that the electromagnetic field strength is $7.18 \times 10-4$ Tesla and the addition of metal core, the weight of the 16 gram catalyst and the length of time the electromagnetic field induction for 90 minutes is obtained as a result of a large reduction in lignocellulose

The time of electromagnetic field induction and the amount of catalyst shows the effect on the amount of condensate (bio-oil) obtained. Figure 3 indicates the relationship between the time of electromagnetic field induction and the weight of the catalyst for the acquisition of bio-oil. 


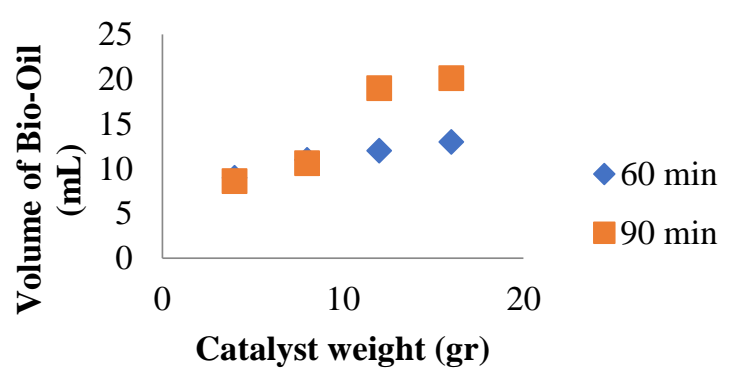

Figure 3 The relationship between variations in the time of electromagnetic field induction and the weight of the catalyst for the aquisition of bio-oil.

From the Figure 3, the acquisition of bio-oil increases with the length of time the electromagnetic field induction is used. At 90 minutes the bio-oil volume is greater than 60 minutes. This is because the time given is able to influence the direction of this magnetic moment so that its direction is parallel to the direction of the electromagnetic field and causes the molecular activity of the material to increase, so the catalytic cracking process will produce a large volume of bio-oil.

The use of electromagnetic field induction in the catalytic cracking process of lignocellulose is a new technology. Electromagnetic field induction on a material can affect the molecular activity of materials. The atomic nucleus of a molecule is like a small electromagnetic field that resides in orbital's with certain energy levels which, when subjected to external electromagnetic fields, are subjected to excitation [6].

The variation in the weight of the catalyst also affects the acquisition of bio-oil. The acquisition of bio-oil increases with the amount of catalyst given. This is due to catalyst activity which has a role in increasing catalytic selectivity [16]. The greater the number of catalysts used, the greater the component of cellulose, hemicellulose and lignin decomposition in the catalyst cavity [17]. The addition of a catalyst that causes the addition of the volume of bio-oil obtained is due to the cation donor given the catalyst. A large catalyst ratio is needed to speed up the cracking process, where the greater the catalyst ratio, the greater the active surface of the catalyst [18]. This is reinforced by the statement of Lestari [19], that by increasing the percentage of weight of the catalyst to biomass with uniform particle size shows that the amount of pore in the catalyst is increasing so that the surface area will be even greater. In this study the largest volume of bio-oil was obtained with a weight of 16 grams of catalyst.

\subsection{Characteristics of Bio-Oil}

The result of the characterization test of the physical properties of bio-oil from cassava stems can be seen in Table 2.

Table 2. Some physical properties of the produced biooil.

\begin{tabular}{|c|r|r|r|}
\hline $\begin{array}{c}\text { Electromagnetic } \\
\text { Induction } \\
\text { (min) }\end{array}$ & $\begin{array}{r}\text { Catalyst } \\
\text { Weight } \\
\text { (gram) }\end{array}$ & \multicolumn{1}{c|}{$\begin{array}{c}\text { Density } \\
\text { (gr/mL) }\end{array}$} & \multicolumn{1}{c|}{$\mathrm{pH}$} \\
\hline \multirow{4}{*}{60} & 4 & 0.9786 & 2.8 \\
\cline { 2 - 4 } & 8 & 0.9792 & 2.8 \\
\cline { 2 - 4 } & 12 & 0.9795 & 2.8 \\
\cline { 2 - 4 } & 16 & 0.9803 & 2.8 \\
\hline \multirow{4}{*}{90} & 4 & 0.9787 & 2.8 \\
\cline { 2 - 4 } & 8 & 0.9813 & 2.8 \\
\cline { 2 - 4 } & 12 & 0.9826 & 2.8 \\
\cline { 2 - 4 } & 16 & 0.9838 & 2.8 \\
\hline
\end{tabular}

From Table 2, it can be seen that the characteristic bio-oil test consisting of density and $\mathrm{pH}$ as a whole ranges between $0.9786-0.9838 \mathrm{~g} / \mathrm{ml}$ which has met Dynamotive standards, which is $0.94-1.2 \mathrm{~g} / \mathrm{ml}$ depending on the amount of the content water. The results of bio-oil $\mathrm{pH}$ measurements in this study were 2.8 according to VTT Technology 87 [20] standards, namely 2-3. Acidity that occurs is due to the presence of acetic acid and other acids due to a process that breaks down cellulose and lignin and extractive substances.

\subsection{Gas Chromatography Mass Spectroscopy (GC-MS) Analysis}

GC-MS analysis was performed to determine the composition of bio-oil. The product that produces the most bio-oil volume is obtained at run 4 and run 8 . The length of exposure to electromagnetic field induction in solution gives a significant increase in the volume of bio-oil. Figure 4 shows the results of the chromatogram of bio-oil cassava stem waste with the duration of electromagnetic field induction for 60 minutes and 90 minutes. 


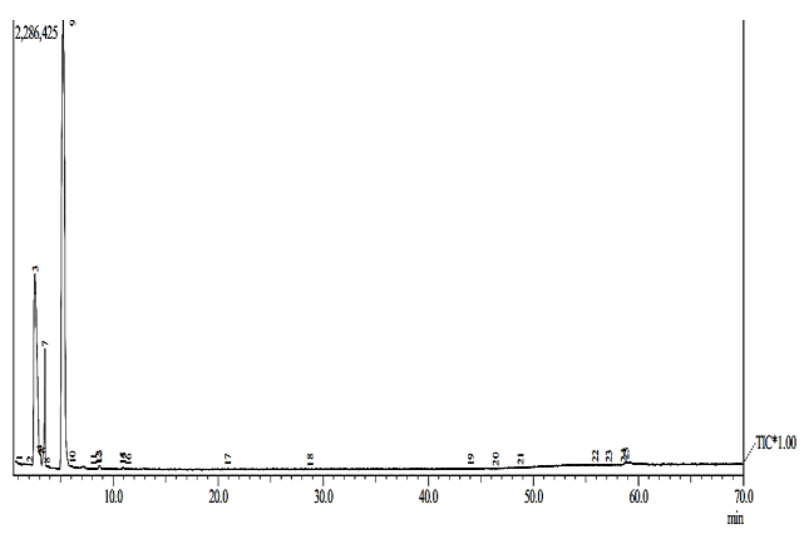

(a)

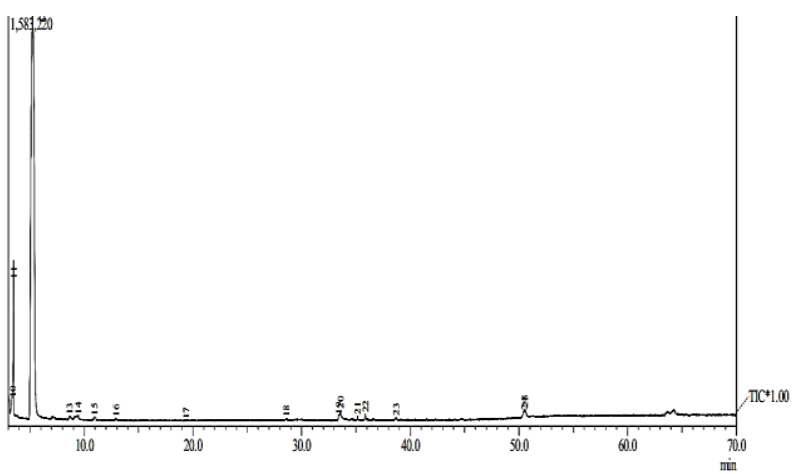

(b)

Figure 4 Chromatogram of bio-oil for (a) 60 minutes and (b) 90 minutes

The results of the chromatogram show that there are 3 dominant peaks, where furfural gives the highest results in all treatments for the length of time of electromagnetic field induction. The bio-oil component of cassava stem waste can be seen in Table 3.

Table 3. Component of bio-oil with electromagnetic field induction.

\begin{tabular}{|c|c|c|c|c|c|c|}
\hline \multirow[t]{2}{*}{ No. } & \multirow[t]{2}{*}{ Component } & \multirow[t]{2}{*}{ Formula } & \multirow{2}{*}{$\begin{array}{c}\text { Mol } \\
\text { Weight }\end{array}$} & \multicolumn{2}{|c|}{ Peak Area (\%) } & \multirow{2}{*}{$\begin{array}{c}\text { Group } \\
\text { Classification }\end{array}$} \\
\hline & & & & $60 \mathrm{~min}$ & $90 \mathrm{~min}$ & \\
\hline 1. & Acetic acid & $\mathrm{C}_{2} \mathrm{H}_{4} \mathrm{O}_{2}$ & 60 & 3.61 & 5.17 & $\begin{array}{l}\text { Organic } \\
\text { compound }\end{array}$ \\
\hline 2. & 2-Furancarboxaldehyde & $\mathrm{C}_{5} \mathrm{H}_{4} \mathrm{O}_{2}$ & 96 & 65.30 & 63.47 & Furans \\
\hline 3 & 5-Methylfurfural & $\mathrm{C}_{6} \mathrm{H}_{6} \mathrm{O}_{2}$ & 110 & 0.04 & 0.37 & Furans \\
\hline
\end{tabular}

\subsection{Fourier Transform Infra Red (FT-IR)}

The product in the form of bio-oil and liquid residue from the catalytic cracking process using electromagnetic field induction was analyzed using Fourier Transform Infrared (FT-IR) to detect the molecular structure of compounds through functional groups making up compounds. The results of FT-IR bio oil analysis can be seen in Figure 4 and liquid residue in Figure 5.

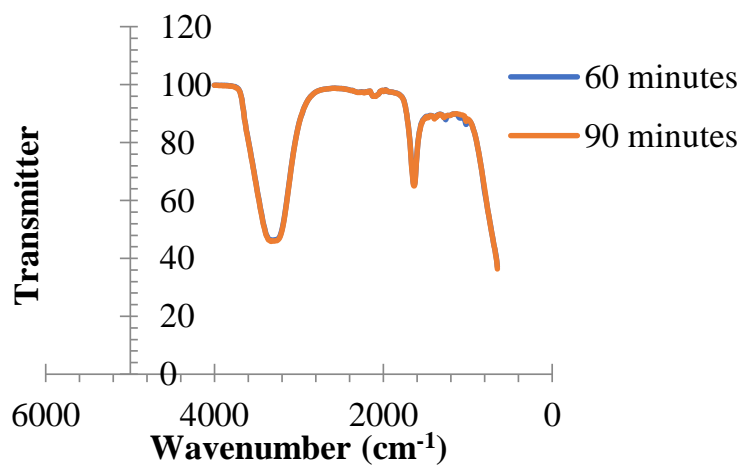

Figure 5 FT-IR spectrum of bio-oil weste cassava stem.
From Figure 5, the spectra graph of FT-IR bio-oil cassava stem waste, the $\mathrm{O}-\mathrm{H}$ strain provides a strong absorption band at wave number $3332.2 \mathrm{~cm}-1$. Hydrogen bonds are formed between hydrogen atoms from another hydroxyl group of glucose monomers in the cellulose polymer chain. Wave number $2124.6 \mathrm{~cm}-1$ is a peak caused by a vibration of $\mathrm{C} \equiv \mathrm{C}$ which indicates the presence of lignin. At wave number $1640.0 \mathrm{~cm}-1$ shows the presence of aromatic and aliphatic groups $(\mathrm{C}=\mathrm{C})$. At wave numbers and $1259.8 \mathrm{~cm}-1$ and $1021.3 \mathrm{~cm}-1$ indicate the presence of an ester group (C-O) [21]. 


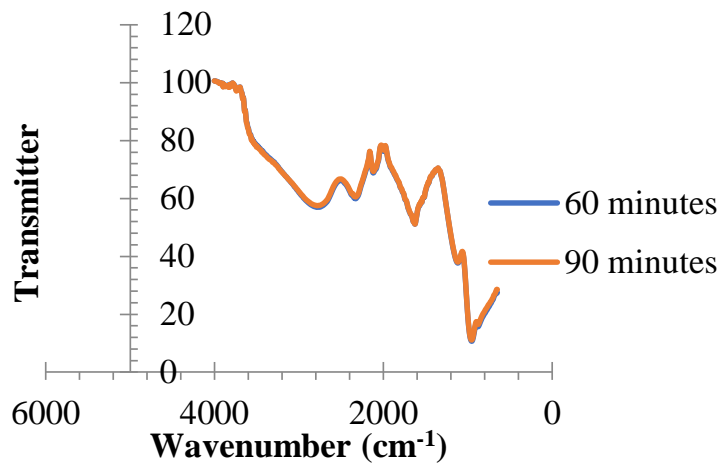

Figure 6 FT-IR spectrum of liquid residues of cassava stem waste.

From FT-IR spectra, liquid residues of cassava stem waste are absorbed at wave numbers greater than 3700 $\mathrm{cm}-1$, this is because alcohol does not contain hydrogen bonds as in gas conditions [21]. C-H bond absorption is at wave number $2788.0 \mathrm{~cm}-1$. Hydrogen bonds are formed between hydrogen atoms from another hydroxyl group of glucose monomers in the cellulose polymer chain. Wave number $2124.6 \mathrm{~cm}-1$ is a peak caused by a vibration of $\mathrm{C} \equiv \mathrm{C}$. There is a wave number $2117.1 \mathrm{~cm}-1$ which shows the $\mathrm{C} \equiv \mathrm{C}$ group bond and wave number $1625.1 \mathrm{~cm}-1$ which shows the $\mathrm{C}=\mathrm{C}$ group bond which indicates the content of lignin. Uptake of other groups is at wave number $1118.2 \mathrm{~cm}-1$ which indicates the presence of a C-N group. At wave number $954.2 \mathrm{~cm}-1$ which shows the vibration of $\mathrm{C}-\mathrm{H}$.

The liquid residue from the catalytic cracking process using electromagnetic field induction has also been analyzed using a UV-Vis spectrophotometer with tannin parameters. From the analysis results obtained phenolic components. Phenol has the tendency to be acidic so it can release $\mathrm{H}+$ ions from its hydroxyl group. In a previous study conducted by Wibowo [22] stated, with various variations of temperature it was stated that with higher temperatures, phenol compounds tended to increase. This is because at high temperatures, the stability of lignin decomposes from the raw material and mixes with the liquid produced by pyrolysis. The content of phenol in liquids is influenced by the content of the raw material lignin and the process temperature. Basically, lignin is a phenol that is very stable and difficult to separate so it will decompose at high temperatures such as in the process of pyrolysis with temperatures between $300-500^{\circ} \mathrm{C}$ [22]. It is possible that phenol compounds cannot be evaporated because the temperature used in this study has not reached the point where lignin can decompose.

\section{CONCLUSION}

The results of this study indicate that cassava stems have the potential as raw materials for bio-oil production. The best characteristic of bio-oil obtained of the study are density $0.98 \mathrm{gr} / \mathrm{ml}, \mathrm{pH} 2.8$ with components acetic acid
$5.17 \%$, 2-furancarboxaldehyde $63.47 \%$ and 5-methyl furfural $0.37 \%$. This achieve with catalyst $16 \mathrm{gr}$ and electromagnetic field 90 minutes. The research results obtained, cassava stems can be used as raw materials in the manufacture of bio-oil.

\section{ACKNOWLEDGMENTS}

This work was supported by BLU-Funding of Universitas Lampung (grant Number 2290/UN26.21/PN/2019) and Ministry of Research and Higher Education Programme of Klinik Penulisan Artikel Ilmiah International (Bogor, 27-28 June 2019).

\section{REFERENCES}

[1] Ministry of Agriculture. 2015. Outlook on Agricultural Commodities Subsector of Cassava Food Crops. Jakarta: Data Center and Agricultural Information System

[2] Lismeri L, U Rhiki Sekti, D Yuli, H Muhammad, and R Agus. 2018. Production of reducing sugars from cassava stems by hydrolysis using dilute acid and electromagnetic field induction. Journal of Chemical and Environmental Engineering, 13(1): 8-14

[3] Xiu, S., \& Shahbazi, A. 2012. Bio-oil production and upgrading research: A review. Renewable and Sustainable Energy Reviews, 16(7):4406414.doi:10.1016/j.rser.2012.04.028

[4] Danarto YC, P B Utomo and FSasmita. 2010. Pyrolysis of wood powder waste with zeolite Catalysts. In Proceedings of the National Chemical Engineering Seminar "Struggle": 1-6. Development of Chemical Technology for the Processing of Indonesian Natural Resources

[5] MuthiaR. 2011. Quality improvement of bio-oil from oil palm empty bunches using the fast pyrolysis method with zeolite catalysts.Essay.Indonesia Univ.

[6] Lismeri L, Haryati S., Bustan D.M.,and Darni Y.2018. Assisted of electromagnetic fields in glucose production from cassava stems.Earth and Environmental Science, 141: 1-12

[7] García, R., Pizarro, C., Lavín, A. G., \& Bueno, J. L. 2013. Biomass proximate analysis using thermogravimetry. Bioresource Technology, 139, 1-4. doi:10.1016/j.biortech.2013.03.197

[8] Hidayat S, M S A Bakar, Y Yang and N Phusunti. 2018. Characterisation and Py-GC/MS analysis of Imperata Cylindrica as potential biomass for bio-oil production in Brunei Darussalam. Journal of Analytical and Applied Pyrolysis, 134: 510-519 
[9] Marliati Ahmad1, Handoko Subawi. 2013. New Van Krevelen diagram and its correlation with the heating value of biomas. Research Journal of Agriculture and Environmental Management. Vol. 2(10), pp. 295-301

[10] Zanatta E Regina, T Olinek Reinehr, J Adb Awadallak, S J Kleinubing, J B O dos Santos, R A Bariccatti, P A Arroyo and E A da Silva. 2016. Kinetic studies of thermal decomposition of sugarcane bagasse and cassava bagasse. J Therm Anal Calorim. 1-9

[11] Nhuchhen D R and A Muhammad T. 2017. HHV predicting correlations for torrefied biomass using proximate and ultimate analyses. Bioengineering, 4(7): 1-15

[12] C. Huang, L. Han, Z. Yang, X. Liu. 2009. Ultimate analysis and heating value prediction ofstraw by near infrared spectroscopy, Waste Manag. 29 1793-1797, https://doi.org/10.1016/j.wasman.2008.11.027

[13] Sathitsuksanoh N, Z Zhu and YH Percival Zhang.2012. cellulose solvent-based pretreatment for corn stover and avicel: Concentrated phosphoric acid versus ionic liquid (BMIM)CI.Cellulose, 1-12

[14] S Osvaldo Z, P Putra S and MFaizal.2012. Effect of acid and time concentration on hydrolysis and bioethanol making fermentation from alangalang.Journal of Chemical Engineering, 18(2): $52-62$

[15] Moosavi F and M Gholizadeh. 2014. Magnetic effect on the solvent properties investigated by molecular dynamics simulation. Journal of Magnetism and Magnetic Materials, 345: 239247

[16] Agustin D, Y Sahan, and S Bahri. 2014. Converting avocado seeds into bio-oil with pyrolysis Method using natural zeolite catalysts.Jurnal Online Mahasiswa Bidang Teknik dan Sains, 1(1): 1-10

[17] Junaidi W, Sunarno and SBahri.2013. Hydrogenation of palm shell pyrolysis becomes bio-oil with ZSM-5 Catalysts. Jurnal Online MahsiswaBidangTeknikdanSains.Riau. Univ.

[18] Sunarno, D Heltina and S Bahri. 2012. Effect of addition of NiMo / ZSM-5 catalysts on pyrolysis of palm shells to bio-oil.National Seminar on Chemical Engineering in Indonesia IV and APTEKINDO National Conference 2012, 1-5

[19] Lestari D Y. 2010. Study of modifications and characteristics of natural zeolites from various countries.In Proceedings of the 2010 National
Seminar on Chemistry and Chemistry Education, 1-6

[20] Lehto J, A Oasmaa, Y Solantausta, M Kuto and D Chiaramonti. 2013.Fuel oil quality and combustion of fast pyrolusis bio-oils. Finland: VTT Technology 87

[21] Dachriyanus. 2004. Structural analysis of organic compounds by spectroscopy.Reading, Mass.: Andalas Information and Communication Technology Development Institute (LPTIK)

[22] [22] Wibowo S. 2013. Characteristics of biooil in sengon sawdust (ParaserianthesFalcataria L. Nielsen) using a slow pyrolysis process. Journal of Forest Product Research, 31(4): 258270. ISSN: 0216-4329 